\title{
Research on quality assurance in production of ready-mixed
}

\section{concrete in Poland}

\author{
Robert Grygo ${ }^{a}$, Jolanta Harasymiuk ${ }^{b^{*}}$, Andrzej Rudziński ${ }^{b}$ \\ ${ }^{a}$ Department of Building Structures, Faculty of Civil \& Environmental Engineering, \\ Bialystok University of Technology, Wiejska str. 45e, PL 15-351 Bialystok, Poland \\ b Institute of Building Engineering, Faculty of Geodesy, Geospatial and Civil Engineering, \\ University of Warmia and Mazury in Olsztyn, Heweliusza str. 4, PL 10-724 Olsztyn, Poland \\ * Corresponding author: Jolanta Harasymiuk, phd eng, jolanta.harasymiuk@uwm.edu.pl
}

\begin{abstract}
The concrete mix is one of the most common materials used in building structures. Starting from 1 July 2018, concrete for construction purposes in Poland must be produced as a part of the Factory Production Control (FPC). A literature review as well as a study of current control practices among the ready-mixed concrete suppliers and an expert survey has shown insufficient preparation of the Polish manufacturers for developing the FPC as a tool for monitoring the quality of concrete production. To deal with this problem, the authors developed an algorithm that shows a group of logically related tasks which are critical to success and may provide manufacturers' guidance in implementing the system in a particular case.
\end{abstract}

Key words: quality assurance, ready - mixed concrete, factory production control, factory production control system, Poland

\section{Introduction}

Concrete is the most commonly used construction material in modern civilization. This is due to its numerous advantages including the ease of its manufacturing and laying, high resistance and hardness, limited environmental impact and relatively low cost of production. According to the data of the Polish Association of Ready Mixed Concrete Manufacturers, (Fig.1), a growing trend was observed with regard to the production volume in years 2012-2016, and should be maintained in 2017. Monolithic concrete is responsible for the stability of a building structure and contributes to other basic structure requirements including fire and health safety, environmental protection, heat insulation, energy savings, and 
sustainable use of natural resources. Therefore, the quality of concrete used in the construction of structures is of key importance for the users of these structures.

Until 31 December 2016, the highest industry standard in organization, technology and quality assurance in production was confirmed by the "Good Concrete” quality mark awarded by the Polish Association of Ready Mixed Concrete Manufacturers (SPBT) (currently held by 80 concrete plants) and/or the Factory Production Control (FPC) certificate (currently held by 74 plants). Relevant qualification procedures were usually followed voluntarily by large and state-of-the-art production plants boasting good equipment, competent staff, and implementation of European quality control procedures. According to (Z.B. Kohutek, 2016) ${ }^{1}$, about 700 concrete production plants in Poland has undergone no external verification of any sort, with more than one half of these plants being unable to meet the new requirements

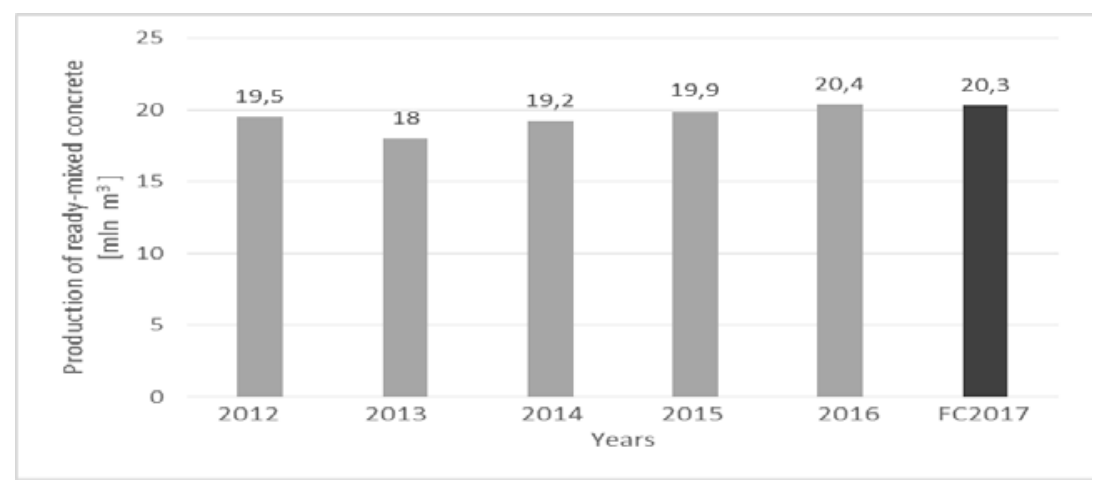

Fig. 1 - Polish production of ready-mixed concrete in years 2012-2016 with 2017 outlook

(based on the data of the Polish Association of Ready Mixed Concrete Manufacturers) without professional support. Starting from 1 July 2018, construction concrete must be produced as a part of the certified FPC system. The objective of the study is to examine and define elements of FPC in accordance with the PN-EN 206+A1:2016-12 standard ${ }^{2}$ as well as certified bodies' requirements and develop an algorithm that will be helpful in developing of the effective FPC system in a concrete plant.

\section{Methodology of research}

The research was commenced with a literature review on requirements of the FPC standards in building industry as well as quality assurance standards. Then an expert survey was conducted in the form of freely directed interviews with experts - members of managerial staff of a concrete plant to study control practices used in manufacturing of ready-mixed concrete. The research was completed with an examination of the existing FPC systems with the aid of participant observation of the organizational units of the quality management 
services as well as the competence and forms of the cooperation of the personnel responsible for the production management and entitled to take measures ensuring concrete quality.

\section{Results and discussion}

FPC is defined as documented, continuous, internal control of the production at the manufacturing plant in line with applicable national technical specifications (Ordinance of the Minister of Infrastructure and Construction ... 2016) ${ }^{3}$. The scope of the control should encompass the entire manufacturing process (N.M. De Almeida et al. 2015) ${ }^{4}$ starting from the selection of concrete ingredients, process design, production, verification and testing, utilization of test results, to inspections of concrete mix transport equipment and product compliance checks. The FPC system should consist in an adequate organizational structure, processes, procedures and resources necessary to develop, implement and maintain the system. The main objective for it is to ensure that the customers will receive the products with stable parameters compliant with the requirements of the PN-EN 206+A1:2016-12 standard as declared in the reference document (declaration of performance characteristics).

The requirement of implementing of the FPC for ready - mixed concrete suppliers has been imposed in Poland at the moment of its becoming an EU member. However, compliance with the FPC requirements turned out to be challenging for many manufacturers. Problems consisted e.g. in the lack of guidelines regarding the recording of activities (J. Deszcz 2015) ${ }^{6}$. A guideline for factory production control for construction materials (J. Bobrowicz et al. 2006) ${ }^{7}$ was published by the Building Research Institute Guideline in 2006, but was not available for all manufacturers. As a consequence, FPC systems lacked completeness and integrity and thus were inefficient. Despite the fact that, according to Polish regulations, concrete was not a construction product until the end of 2016, general requirements for the Factory Production Control were defined as early as in the PN-EN 206:2004 standard. If the manufacturer wanted to declare the performance characteristics of their concrete product as compliant with the standard, a documented production control system should have been in place at their facilities. However, the efficacy of such systems was not subject to verification by means of objective, external audits. The main difference following introduction of the PN-EN 206+A1:2016-12 standard (in force since 13 December 2016) as compared to the PN-EN 206:2014-04 ${ }^{5}$ standard (in force between 23 January 2015 to 12 December 2016) consists in the obligatory nature of certification as opposed to its being voluntary pursuant to previous regulations (with concrete not being classified as intended for 
construction/non-construction use). Table 1 lists the manufacturer's actions that need to be monitored as part of the FPC system according to PN-EN 206+A1:2016-12 and expert survey. The algorithm, elaborated by the authors, identifies necessary stages to develop the FPC system in a concrete plant, regardless of a usage of concrete. These stages are shown in Fig. 2. Additionally, the concrete standards' review and the expert survey revealed these aspects of implementing and maintaining the system which may be considered as problematic. They have been analyzed below.

The role of preliminary tests of concrete products as described in Appendix A to the PN-EN 206+A1:2016-12 standard is insufficiently highlighted. Similar approach is also presented by certain bodies offering consulting services with regard to the FPC system development and implementation. The manufacturer produces and sales optimized, i.e. parameter- and costadjusted concrete mixes with specific compositions. Preliminary tests should be carried out and national declaration of performance characteristics should be issued for each of these mixes. This, however, should not constitute the last stage of manufacturer's involvement as it might lead to insufficient efficiacy of the entire system (market reports are available on manufacturers having developed the FPC system and obtained the certificate of conformity with the PN-EN 206+A1:2016-12 standard yet few potential customers being able to afford the products).

Section 9 and Appendix C to the PN-EN 206+A1:2016-12 standard insufficiently highlights the scope of the manufacturer's operations requiring established and documented procedures. This may result in the system being too bureaucratized. As seen from observational studies, the control procedures for ready-mixed and hardened concrete as well as the specifications of testing equipment are largely based on the requirements of the standard. The description of the procedure may only refer to the standard instead of quoting its contents. However, valid copies of the standard should be available at worksites. What's more, manufacturers of ready -mixed often increase the specificity of the general standard requirements to increase the applicability of the system used. In such cases, additional requirements set forth in FPC documentation must also be met and taken into account in conformity assessment. The meeting of these requirements should also fall within the scope of the audit performed by the 


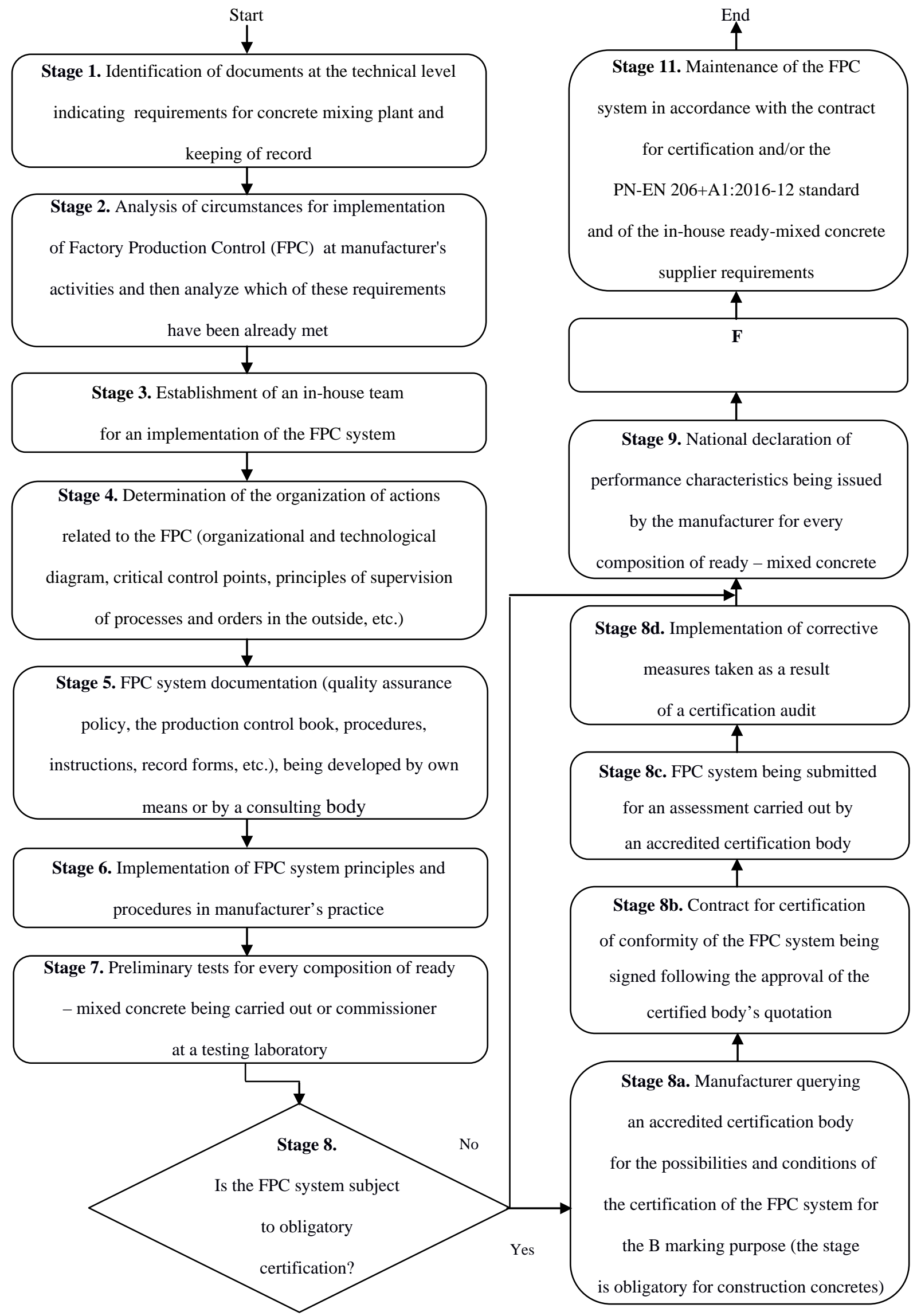

Fig. 2 - Flow chart to identify critical stages of implementing the FPC system 
Table 1 - Areas subject to documented supervision as part of the factory production control system at a ready-mixed concrete manufacturing plant (1 of 2)

\begin{tabular}{|c|c|c|}
\hline Area & Method of implementation & Objective \\
\hline \multicolumn{3}{|l|}{ Organization } \\
\hline $\begin{array}{l}\text { Responsibilities, } \\
\text { powers } \\
\text { and interrelationships } \\
\text { between individual } \\
\text { organizational units } \\
\text { within the FPC system }\end{array}$ & $\begin{array}{l}\text { Definition of responsibilities and powers } \\
\text { of personnel at individual positions; } \\
\text { Identification of the relationship between the } \\
\text { management, operation and control teams }\end{array}$ & $\begin{array}{l}\text { Means to assure: } \\
\text { - competences required for the } \\
\text { achievement of FPC program } \\
\text { goals; } \\
\text { - mutual independence between } \\
\text { the management, operation, } \\
\text { and control teams }\end{array}$ \\
\hline $\begin{array}{l}\text { Person responsible for } \\
\text { the FPC system }\end{array}$ & $\begin{array}{l}\text { Establishment and empowerment of a FPC } \\
\text { representative }\end{array}$ & $\begin{array}{l}\text { Means to assure complete } \\
\text { supervision of the implemented } \\
\text { system }\end{array}$ \\
\hline $\begin{array}{l}\text { Supervision of the } \\
\text { management team }\end{array}$ & $\begin{array}{l}\text { System control and evaluation by the } \\
\text { management team in determined time } \\
\text { intervals (not less than once for } 2 \text { years) }\end{array}$ & $\begin{array}{l}\text { Means to assure management } \\
\text { team’s involvement in the } \\
\text { development and maintenance } \\
\text { of the system }\end{array}$ \\
\hline \multicolumn{3}{|l|}{ Product manufacturing } \\
\hline Production control & $\begin{array}{l}\text { Definition of rules for: } \\
\text { - } \quad \text { the control of the ready-mixed concrete } \\
\text { process and status assignment; } \\
\text { - } \text { the control of production procedures and } \\
\text { properties of ready-mixed concrete with } \\
\text { identification of responsibilities; } \\
\text { - } \text { identifiability (at each stage of ready } \\
\text {-mixed concrete manufacturing process) } \\
\text { and traceability with identification of } \\
\text { responsibilities; } \\
\text { - } \text { management of complaints }\end{array}$ & $\begin{array}{l}\text { Means to assure: } \\
\text { - } \text { product conformity to } \\
\text { technical specification; } \\
\text { - } \text { reduced susceptibility of the } \\
\text { manufacturing process to } \\
\text { external disturbance; } \\
\text { - identifiability of product } \\
\text { batches and parameters; } \\
\text { supervision of non-conforming } \\
\text { products (for own as well as } \\
\text { customer purposes) }\end{array}$ \\
\hline Transport & $\begin{array}{l}\text { Identification of methods and means to ensure } \\
\text { stable quality of ready-mixed concrete upon } \\
\text { the delivery to the customer. }\end{array}$ & $\begin{array}{l}\text { Means to assure test-confirmed } \\
\text { quality of the concrete mix }\end{array}$ \\
\hline \multicolumn{3}{|l|}{ Tests and controls } \\
\hline $\begin{array}{l}\text { Facilities and process } \\
\text { equipment }\end{array}$ & $\begin{array}{l}\text { Definition of rules for: } \\
\text { - } \text { inspections of concrete mix transport } \\
\text { equipment (lorry-based concrete mixers, } \\
\text { self-tipping lorries), balances, water and } \\
\text { additive dispensers, aggregate humidity } \\
\text { meters, mixers, etc.) with identification or } \\
\text { responsibilities; } \\
\text { - } \\
\text { verification, calibration (laboratory } \\
\text { balances, pressure gauges) and } \\
\text { maintenance of control, measurement and } \\
\text { testing equipment with identification of } \\
\text { responsibilities }\end{array}$ & $\begin{array}{l}\text { Means to assure: } \\
- \text { good technical condition } \\
\text { of equipment and facilities } \\
\text { meeting the requirements of } \\
\text { the PN-EN 206+A1:2016-12 } \\
\text { standard } \\
-\quad \text { reliability and repeatability } \\
\text { of tests and measurements }\end{array}$ \\
\hline Suppliers & Qualification and evaluation of suppliers & $\begin{array}{l}\text { Means to assure suppliers' tasks } \\
\text { being completed in line with the } \\
\text { manufacturer's (commissioner's) } \\
\text { requirements }\end{array}$ \\
\hline
\end{tabular}


Table 1 - Areas subject to documented supervision as part of the factory production control system at a ready-mixed concrete manufacturing plant (1 of 2)

\begin{tabular}{|c|c|c|}
\hline Area & Method of implementation & Objective \\
\hline Concrete ingredients & $\begin{array}{l}\text { Supervision of storage and unloading or } \\
\text { concrete ingredients; } \\
\text { Supervision of the delivery vs. order } \\
\text { compliance with identification of } \\
\text { responsibilities; } \\
\text { Qualitative and quantitative control of the } \\
\text { deliveries with identification or } \\
\text { responsibilities }\end{array}$ & $\begin{array}{l}\text { Means to assure high quality } \\
\text { ingredients free of excessive } \\
\text { quantities of hazardous } \\
\text { substances that might reduce the } \\
\text { durability of concrete or result in } \\
\text { the corrosion of reinforcement } \\
\text { materials. }\end{array}$ \\
\hline $\begin{array}{l}\text { Control frequency and } \\
\text { location, sampling and } \\
\text { tests }\end{array}$ & $\begin{array}{l}\text { List of test frequencies and sample collection } \\
\text { sites meeting the minimum requirements of } \\
\text { the PN-EN 206+A1:2016-12 standard }\end{array}$ & $\begin{array}{l}\text { Means to assure tests being } \\
\text { performed in line with the } \\
\text { requirements of the PN-EN } \\
206+A 1: 2016-12 \text { standard }\end{array}$ \\
\hline $\begin{array}{l}\text { Conformity } \\
\text { of concrete }\end{array}$ & $\begin{array}{l}\text { Assessment of the conformity with the } \\
\text { requirements (criteria) set forth in the PN-EN } \\
\text { 206+A1:2016-12 standard. }\end{array}$ & $\begin{array}{l}\text { Means to assure the conformity } \\
\text { of the parameters of concrete } \\
\text { with the requirements (criteria) } \\
\text { set forth in the PN-EN } \\
206+\mathrm{A} 1: 2016-12 \text { standard }\end{array}$ \\
\hline \multicolumn{3}{|l|}{ System maintenance } \\
\hline Documents and data & $\begin{array}{l}\text { Supervision of external and internal } \\
\text { documentation. }\end{array}$ & $\begin{array}{l}\text { Means to assure unified } \\
\text { performance of process activities } \\
\text { including production control, } \\
\text { purchases, verification of } \\
\text { materials and the assessment of } \\
\text { the efficacy of the FPC system; } \\
\text { Means to assure the relevance } \\
\text { of the documents used }\end{array}$ \\
\hline Records & $\begin{array}{l}\text { Recording of activities, results, and FPC } \\
\text { inspections } \\
\text { Final product marking }\end{array}$ & $\begin{array}{l}\text { Means to assure supervision } \\
\text { of records, including supervision } \\
\text { of the issuance of performance } \\
\text { characteristics }\end{array}$ \\
\hline $\begin{array}{l}\text { Products non- } \\
\text { compliant with the } \\
\text { requirements of the } \\
\text { PN-EN 206+A1:2016- } \\
12 \text { standard, factory } \\
\text { requirements or } \\
\text { customer requirements }\end{array}$ & $\begin{array}{l}\text { Identification of methods for handling non- } \\
\text { compliant products }\end{array}$ & $\begin{array}{l}\text { Means to assure the manufacturer } \\
\text { and the customer that the product } \\
\text { of inappropriate characteristics } \\
\text { will not be used in a building } \\
\text { structure }\end{array}$ \\
\hline FPC system checkups & $\begin{array}{l}\text { Definition of the frequency and principles of } \\
\text { system checkups }\end{array}$ & $\begin{array}{l}\text { Assurance of proper functioning } \\
\text { of the system and of the } \\
\text { possibilities for its improvement. }\end{array}$ \\
\hline
\end{tabular}

certified body during the preliminary inspection of the production facilities and the FPC system as well as during annual supervisory inspections.

Section 9.6.1 of the PN-EN 206+A1:2016-12 standard contains imprecise requirements regarding personnel training. According to the standard, the manufacturer should implement and observe appropriate training procedures for the entire staff as part of the FPC system. Appropriate records should be maintained for all trainings completed. The problem with the above formulation of the requirement consists in the lack of identification whether the trainings are to be held in a one-off or a periodic manner and, in the latter case, with what 
frequency. According to the literal interpretation (i.e. non-overinterpretation) of the standard, it follows that the accredited body (and its auditors) as a party in the process of assessment and verification of the stability of performance characteristics has no grounds to request the establishment of a specific frequency of FPC-related trainings. It can, however, request that every employee involved in the operation of the system, has at least once participated in such training and that records are available to confirm this participation. Individuals employed after the FPC system had been implemented should also undergo training before taking up their duties. According to the authors' experience, the awareness of the nature of factory production control among the plant employees is much higher if supplementary/refresher trainings are offered in a regular fashion.

Continuous improvement constitutes an important element of the FPC system. This requirement is difficult to meet in Polish concrete production plants since they usually lack the tradition of organizational improvement. Hopes for potential improvement are usually associated with the purchase of new technologies.

\section{Conclusions}

In spite of the in-house character of the system, implementation, maintenance and certification of the factory production control (in the case of construction concretes) is a duty of a producer of ready-mixed concrete by the Polish law.

Since 1 July 2018 declaration of usage properties of concrete by a supplier may take place only on the basis of the conducted factory production control. More difficult (because of definitely a higher formality of actions) will be a confirmation of the quality of ready-mixed concrete.

The algorithm, worked out by the authors, identifies stages needed to do it properly. It may be a basis for an analysis of the required documentation and the determination of the needed modification among suppliers of concrete for construction or non-construction purposes.

\section{References}

1. Z. B. Kohutek, Ready-mixed concrete as a construction material, Building Review, No 6 (2016) 12-13 (in Polish).

2. PN-EN 206+A1:2016-12 Concrete - Specification, performance, production and conformity. 
3. Ordinance of the Minister of Infrastructure and Construction of 17 November 2016 on the means for declaring the performance characteristics of construction materials and the the system for labeling the construction products with construction markings (Journal of Laws 2016.1966)

4. N. M. De Almeida, V. Sousa, L. Alves Dias, F. A. Branco, Managing the technical risk of performance-based building structures, Journal of Civil Engineering and Management, Vol. 21(3) (2015) 384-394, DOI:10.3846/13923730.2014.893921.

5. PN-EN 206:2014-04 Concrete - Specification, performance, production and conformity.

6. J. Deszcz, Factory production control in the light of changing legal regulations related to construction products], Building Materials No 3 (2015) 52-53, DOI: 10.15199/33.2015.03.16 (in Polish).

7. J. Bobrowicz, J. Fangrat, J. Gust, B. Jaśpińska, A. Lisowski, Factory production control for construction materials. Requirements - a guideline. No 414/2006, 1st. ed., Building Research Institute, Warsaw, 2006 (in Polish). 